\title{
Concurrent decline of the spawning stock, recruitment, larval abundance, and size of the blue crab Callinectes sapidus in Chesapeake Bay
}

\author{
Romuald N. Lipcius*, William T. Stockhausen \\ Virginia Institute of Marine Science, The College of William and Mary, Gloucester Point, Virginia 23062, USA
}

\begin{abstract}
Conservation of exploited marine populations requires knowledge of interannual variation in the characteristics of and relationships between the spawning stock and recruitment, which determine population resilience and persistence. We examined relationships between spawning stock abundance, postlarval recruitment, larval abundance, and female size of the blue crab in Chesapeake Bay, both within the spawning grounds over a 13 yr interval (1988 to 2000) and within lower-bay tributaries over 20 yr (1979 to 1998). Our findings establish that there has been a concurrent, persistent and substantial reduction in the spawning stock, recruitment, larval abundance, and female size. Specifically, in 1992 to 2000: (1) spawning stock abundance declined by $81 \%$, female size by $8 \%$, and spawning stock biomass by $84 \%$; (2) mean size at maturity $\left(L_{m}\right)$ diminished by $9 \%$; (3) larval abundance and postlarval recruitment were lower by approximately 1 order of magnitude compared with earlier years. The decrease in these variables was rapid, occurring over 1 to $2 \mathrm{yr}$, and therefore indicative of a phase shift in the spawning stock and recruitment, rather than a progressive diminution. We propose that the initial descent resulted from poor recruitment in 1991, despite high spawning stock and larval abundance, and that the poor recruitment in 1991, in concert with high fishing and natural mortality, subsequently led to a diminished spawning stock in 1992 and thereafter. We further suggest that the spawning stock, larval abundance, and recruitment are unlikely to rebound to former high levels without significant reductions in fishing and natural mortality along with enhanced environmental conditions conducive to successful recruitment. The key consequences of a diminished spawning stock and recruitment are a heightened probability of recruitment failure and reduced resilience to demographic and environmental stochasticity. In addition, the relationships between spawning stock abundance (SSA) and larval abundance, SSA and postlarval recruitment, and SSA and female size were positive and significant. The demonstration of a concurrent decrease and significant association between spawning stock abundance and recruitment, larval abundance and female size is unique for the blue crab and for marine invertebrates in general, and indicates an urgent need to conserve the spawning stock for long-term sustainable exploitation and population persistence.
\end{abstract}

KEY WORDS: Conservation $\cdot$ Blue crab $\cdot$ Callinectes sapidus $\cdot$ Spawning stock $\cdot$ Recruitment $\cdot$ Larval abundance $\cdot$ Exploitation

Resale or republication not permitted without written consent of the publisher

\section{INTRODUCTION}

Conservation of exploited populations requires knowledge of variation in the features of the spawning stock that dictate population persistence (Rothschild

*E-mail: rom@vims.edu
1986). Key demographic variables and parameters of the spawning stock include population abundance at Time $t\left(N_{t}\right)$, recruitment relationships, size structure, and mean size at maturity $\left(L_{\mathrm{m}}\right)$. Recruitment and demographic parameters such as $N_{\mathrm{t}}$ and $L_{\mathrm{m}}$ may covary with the spawning stock, which alters expected population trajectories and persistence compared to

() Inter-Research $2002 \cdot$ www.int-res.com 
expectations generated when considering each parameter separately (Beverton \& Holt 1957, Polovina 1989, Hilborn \& Walters 1992, Pollock 1995). The disparity in population trajectories due to covarying versus independent parameters may make the difference between population persistence and collapse.

Many exploited species display a reduction in mean size or $L_{\mathrm{m}}$ with $N_{\mathrm{t}}$ (Beverton \& Holt 1957, Pollock 1995). Examples include the cod Gadus morhua (Hansen 1949, Beacham 1983, Jorgensen 1990), the hake Merluccius capensis and M. paradoxus (Payne 1989), and the pilchard Sardinops ocellata (Shelton \& Armstrong 1983). The importance of deviations in mean size or $L_{\mathrm{m}}$ with $N_{\mathrm{t}}$ is related to the effects of these parameters on annual and lifetime egg production (Pollock 1995). When size-selective exploitation is high, it may cause selection of heritable traits such as mean size or $L_{\mathrm{m}}$ (Policansky 1993). Furthermore, when demographic parameters vary with abundance, application of static yield-per-recruit (YPR) models may be misleading (Polovina 1989). For instance, in the Hawaiian spiny lobster, Panulirus marginatus, the minimum size that maximizes YPR varied considerably with population abundance from $41 \mathrm{~mm}$ carapace length (cl) at high abundance to $67 \mathrm{~mm} \mathrm{cl}$ at low abundance (Polovina 1989). Estimates of YPR would be reduced by $20 \%$ when using the $41 \mathrm{~mm} \mathrm{cl}$ size rather than the correct $67 \mathrm{~mm} \mathrm{cl}$ size at low population abundances. Thus, the identification of significant covariation between demographic parameters such as $L_{\mathrm{m}}$ with $N_{\mathrm{t}}$ is essential to the wise use of sustainable resources.

Measurement of covariation between demographic parameters such as $L_{\mathrm{m}}$ and $N_{\mathrm{t}}$ rarely has been documented in populations of exploited species such as crabs and lobsters (Pollock 1995, Jamieson 2001). A relationship between $N_{\mathrm{t}}$ and mean size has been demonstrated for the Dungeness crab Cancer magister (Jamieson et al. 1998), and $L_{\mathrm{m}}$ was shown to covary with $N_{\mathrm{t}}$ in Hawaiian spiny lobster Panulirus marginatus (Polovina 1989). In the American lobster Homarus americanus, high exploitation can produce smaller lobsters and lowered larval output (Campbell \& Robinson 1983). In addition, size-selective exploitation of marine crustaceans, often removing the largest individuals, is a common management goal that increases the likelihood of alterations in demographic parameters or lifehistory traits (Jamieson 2001).

Similarly, recruitment may covary with spawning stock abundance (Rothschild 1986), although the relationship is characteristically variable for marine species (Hilborn \& Walters 1992). In marine invertebrates, definition of a significant spawning stock-recruitment relationship (SSR) has been elusive, whether for unexploited (Hughes et al. 2000) or exploited (Hancock 1973) species. In those species exhibiting a significant
SSR, the relationship has often been weak or dependent on environmental and biotic conditions (Lipcius \& van Engel 1990, Caputi et al. 1995, Hannah 1999). However, the empirical evidence is mounting for the importance of the SSR for various marine invertebrates, including acroporid corals (Hughes et al. 2000), penaeid shrimp (Garcia 1996, Rothlisberg et al. 1996, Condie et al. 1999, Ye 2000), pandalid shrimp (Hannah 1999), spiny lobster (Caputi et al. 1995, Medley \& Ninnes 1997), clawed lobster (Ennis \& Fogarty 1997), and king crab (Zheng et al. 1995). For the blue crab, Callinectes sapidus, the SSR has been measured using various indices of abundance for the spawning stock and recruits (Tang 1985, Lipcius \& Van Engel 1990, Kahn et al. 1998, Rugolo et al. 1998, Uphoff 1998), although none of these measured both the spawning stock and postlarval recruitment directly. Hence, we provide an analysis of yearly variation and the relationships between spawning stock abundance, postlarval recruitment, larval abundance, female size, and size at maturity of the blue crab population in Chesapeake Bay.

The blue crab is ubiquitous and heavily exploited in shallow coastal and estuarine habitats of the Northwest Atlantic, Gulf of Mexico and Caribbean Sea (Williams 1984). In late spring through early fall, newly-fertilized adult females make pre-spawning migrations to the lower reaches of estuaries, such as the Chesapeake Bay mouth (Van Engel 1958). In Chesapeake Bay, maximum egg extrusion and larval release occur in summer, principally from July through mid-September either as a single mid-summer peak or as bimodal early-summer and late-summer peaks (Jones et al. 1990, Prager 1996). Females hatch up to $8 \times 10^{6}$ larvae (Prager et al. 1990) near the mouth of the estuary. Larvae are transported to the continental shelf where they develop through 7 to 8 zoeal stages (Costlow \& Bookhout 1959, McConaugha et al. 1983, Provenzano et al. 1983) before metamorphosis to the megalopal (postlarval) stage, which reinvades estuarine nursery grounds such as seagrass beds (Costlow 1967, Epifanio et al. 1989, Mense \& Wenner 1989, van Montfrans et al. 1990, 1995). The seasonally synchronized and spatially localized abundance of spawning females, larvae, and recruiting postlarvae presents a unique opportunity to define the relationships between female size, spawning stock abundance, larval abundance, and postlarval recruitment.

Interannual variation in population abundance of the blue crab is substantial throughout its range, including Chesapeake Bay (Lipcius \& Van Engel 1990, Abbe \& Stagg 1996, Rugolo et al. 1998, Uphoff 1998), Delaware Bay (Kahn et al. 1998), the Gulf of Mexico (Guillory \& Perret 1998, Hammerschmidt et al. 1998, Perry et al. 1998) and the Atlantic coast (Whitaker et al. 1998). 
However, the relationships between adult female size, spawning stock abundance, larval abundance, and postlarval recruitment have not been documented, usually because the spawning stock, larval abundance, and recruitment were not directly sampled or because adult female size was neither measured nor reported. For instance, adult female size and abundance varied independently in the upper and middle reaches of Chesapeake Bay (Uphoff 1998), which is outside the main spawning grounds. In 2 Gulf of Mexico locations, abundance of adults and mean size in the population, including juveniles, declined concurrently over 1 to 2 decades, but this pattern was interpreted as an increase in the relative abundance of juveniles in the population, and not as a decline in adult female size (Guillory \& Perret 1998, Hammerschmidt et al. 1998). This pattern may actually have been due to a simultaneous decline in female size rather than to the relative abundance of juveniles. The average size of large male blue crabs has decreased significantly over the past decade in the middle and upper reaches of Chesapeake Bay (Abbe \& Stagg 1996), suggesting that a significant alteration in demographic features of the adult segment of the population has occurred. This investigation represents the only documented analysis of female size, spawning stock abundance, larval abundance, and postlarval recruitment for the blue crab, and one of the few for marine invertebrates.

\section{METHODS}

Field sites and sampling. Females, larvae and postlarvae were collected as follows:

Adult females: Adult female Callinectes sapidus were sampled both within the spawning grounds over a $13 \mathrm{yr}$ interval (1988 to 2000) and within lower-bay tributaries (James, York and Rappahannock Rivers) over 20 yr (1979 to 1998) with a stratified, random trawl survey in lower Chesapeake Bay (Fig. 1). Details of sampling are given by Lipcius \& Van Engel (1990) and Hata (1997). Each value from a single tow served as an independent datum (i.e., number of adult females tow $^{-1}$ or size in $\mathrm{mm}$ carapace width [cw]). Average sample sizes in the spawning grounds were $40 \mathrm{mo}^{-1}$ $($ minimum $=33)$ and $120 \mathrm{yr}^{-1}($ minimum $=99)$, while in the tributaries they were about $60 \mathrm{mo}^{-1}$ in all tributaries combined and approximately $180 \mathrm{yr}^{-1}$. The trawl survey has undergone minor changes in sampling protocol since 1979 (Hata 1997), requiring use of gearconversion factors to standardize abundance values. For the lower bay samples where we measured the spawning stock, only data from July 1988 to September 1990 required standardization, whereas in the tributaries the data from 1979 to 1990 required minor cor- rections (Hata 1997). Although analyses with uncorrected data yielded nearly equivalent statistical results, all analyses herein use the standardized data.

Adult female blue crabs release larvae in the lower reaches of Chesapeake Bay each year from late June or early July through late September (Van Engel 1958, Jones et al. 1990). Hence, an accurate measure of the spawning stock requires sampling of adult females in the spawning grounds of lower Chesapeake Bay from July through September. Our lower-bay samples were taken monthly in the spawning grounds (Fig. 1) from July through September during a $13 \mathrm{yr}$ time period (1988 to 2000), and therefore provide a direct estimate of the spawning stock.

Sampling in the lower bay began in 1988. To provide a longer time series, we utilized trawl survey data for 1979 to 1998 from the James, York and Rappahannock Rivers (Fig. 1). Although this series extends back before 1979, the data set prior to 1979 is characterized by various gear changes, necessitating further assessment before standardization. Hence, we limited our analyses to trawl survey data from July through Sep-

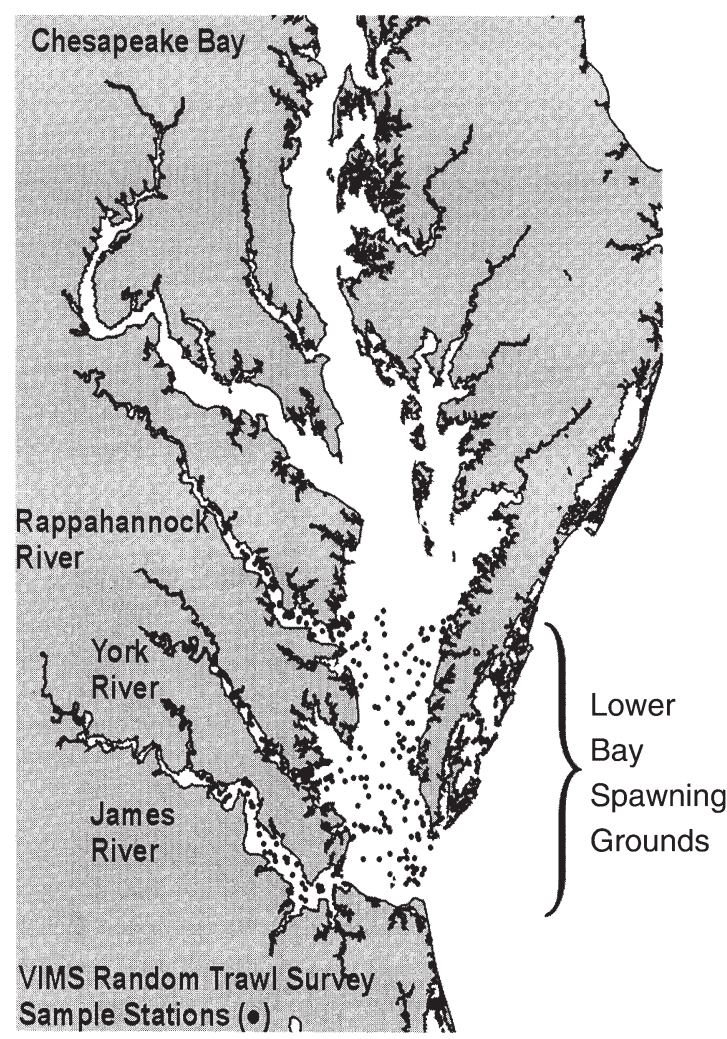

Fig. 1. Representative sampling stations of the Virginia Institute of Marine Science (VIMS) trawl survey in lower Chesapeake Bay spawning grounds and tributaries (James, York and Rappahannock Rivers) for 1997. Stations were sampled monthly from July to September 
Table 1. Sampling sites for Callinectes sapidus larvae and postlarvae in plankton samples collected by R. Birdsong and K. Carpenter (Department of Biological Sciences, Old Dominion University, Norfolk, Virginia) under the auspices of the Chesapeake Bay Monitoring Program. Larval data included samples from June through September, while postlarval data were from June through December, the periods when these stages were found in the plankton

\begin{tabular}{|ll|}
\hline Station No. & \multicolumn{1}{c|}{ Location } \\
\hline CB6.1 & Main channel, mid-Chesapeake Bay \\
CB6.4 & Main channel, mid-Chesapeake Bay \\
CB7.3E & Chesapeake Bay eastern shore channel, \\
& southern end \\
CB7.4 & Chesapeake Bay mouth, Baltimore channel \\
LE5.5 & James River mouth \\
WE4.2 & York River mouth \\
LE3.6 & Rappahannock River mouth \\
\hline
\end{tabular}

tember in the James, York and Rappahannock Rivers during a 20 yr time period (1979 to 1998) as a surrogate measure for the Chesapeake Bay spawning stock. Data sets from the lower bay and the 3 tributaries were correlated to test the validity of using the tributary data as a surrogate measure of spawning stock abundance in the lower bay spawning grounds.

Larvae and postlarvae: Data on concentrations of blue crab larvae and postlarvae in the plankton were derived from plankton samples (Table 1) collected under the auspices of the Chesapeake Bay Monitoring Program (http://www.chesapeakebay.net/monprgms. htm) by R. Birdsong and K. Carpenter (Department of Biological Sciences, Old Dominion University, Norfolk, Virginia) from 1985 to 1999. Larval samples were collected from June through September, while postlarval samples were from June through December, the times when these stages were found in the plankton. The sampling stations were located either in the Chesapeake Bay mainstem or near the mouth of each of the major tributaries in the lower Bay (Rappahannock, York, and James Rivers), which delimits the spawning grounds of the blue crab (Lipcius et al. 2002b).

Plankton samples were collected and processed according to established methods (Alden et al. 1982, Birdsong 1992), and involved a stepped oblique tow (5 to $10 \mathrm{~min}$, depending on zooplankton abundance) through the entire water column at each station with paired bongo nets. Steps were taken in 1 to $4 \mathrm{~m}$ increments, depending on station depth, with 5 step-levels station ${ }^{-1}$. Each net had an attached flow meter, which was used to calculate water volume as follows. The distance traveled by the bongo net during a tow was calculated as (stop revolution number start revolution number) $\times$ blade constant, where stop and start revolution numbers were the number of revolutions recorded on the flow meter at the end and beginning of each tow, respectively, and the blade constant was 26873 . The sample volume was calculated as the product of the distance traveled by the bongo net and area, where area $=0.18776 \mathrm{~m}^{2}$. The mean of each set of samples was used in analyses as the number of larvae or postlarvae $100 \mathrm{~m}^{-3}$.

Abundance and size. Abundance is presented as the arithmetic mean because it portrays proportional changes in abundance. In parametric analyses, abundance was analyzed as the log-transformed $(\log [10 x+$ 1]), standardized number of adult females tow ${ }^{-1}$ to normalize the data and reduce heterogeneity of variance (Underwood 1997). The data were increased by a factor of 10 to minimize the effect upon the remaining data of adding 1 to 0 values. In all cases, variances were either not heterogeneous (Cochran's $C$ statistic), or the $F$ test in analyses of variance was rejected at an $\alpha$ level lower than that used in the test for homogeneity of variance (Underwood 1997).

To analyze the effect of year on abundance, we first determined the degree of correlation between the monthly abundances within each year. These monthly abundance values were significantly and positively correlated (Table 2), but without apparent pattern between the 3 months (paired $t$-tests, Bonferroni adjusted $\mathrm{p}>0.05$ ). For the analysis of abundance, we lacked 1 data point (August 1998). Given the significant correlations between months, we used the mean of the values for July and September as the value for August 1998, and reduced the error degrees of freedom by 1 in the analysis of variance (Underwood 1997).

Table 2. Callinectes sapidus. Matrix of Pearson cross-correlations for annual adult female abundance by month. Significance levels are indicated parenthetically. In all cases, the correlations were conducted for 1989 to 1997 when sampling was conducted each month. In 1998, there were no samples for August, precluding the use of 1998 data in this analysis

\begin{tabular}{|c|c|c|c|}
\hline \multirow[t]{2}{*}{ Variable } & \multicolumn{3}{|c|}{ Comparison } \\
\hline & July-August & July-September & August-September \\
\hline Abundance & $0.89(\mathrm{p}=0.001)$ & $0.70(p=0.023)$ & $0.84(p=0.004)$ \\
\hline Size & $0.84(\mathrm{p}=0.004)$ & $0.79(p=0.011)$ & $0.85(p=0.004)$ \\
\hline Weight & $0.86(\mathrm{p}=0.002)$ & $0.79(p=0.006)$ & $0.85(\mathrm{p}=0.002)$ \\
\hline Biomass & $0.95(\mathrm{p}<0.001)$ & $0.80(p=0.005)$ & $0.89(p=0.001)$ \\
\hline Larval production & $0.92(\mathrm{p}<0.001)$ & $0.76(p=0.012)$ & $0.87(p=0.001)$ \\
\hline
\end{tabular}


Mean size per month was used in size analyses rather than all individual crab sizes because mean size provided an independent data value for parametric analyses (e.g., analysis of variance), whereas individual crabs were not independent of tow and could not be considered replicates in parametric analyses. Monthly values of mean size per tow and mean size of all individual crabs were highly correlated $\left(\mathrm{r}^{2}=0.94\right.$, $\mathrm{df}=1,26, \mathrm{p}<0.0005)$. Hence, we have utilized the mean size per mo as an independent datum in our analyses. These size data did not require transformation to meet assumptions of normality and homogeneity of variance. Patterns between size and abundance were analyzed with non-linear regression.

As with abundance, we analyzed the effect of year on size, and determined the degree of correlation between the monthly abundances within each year. These monthly sizes were significantly and positively correlated (Table 2), without apparent pattern between the 3 months (paired $t$-tests, Bonferroniadjusted $\mathrm{p}>0.05)$. As before, we used the mean of the values for July and September as the value for August 1998, and reduced the error degrees of freedom by 1 in the analysis of variance (Underwood 1997).

Weight and biomass. The mean weight of adult females and spawning stock biomass were calculated from the abundance and size data, as well as ancillary data on the size-weight relationship for adult females. The size-weight relationship was derived from an independent survey (Rothschild \& Ault 1992, Lipcius et al. 2002a), and analyzed with a least-squares linear regression. Although the size-weight relationship was measured for adult females in the winter, these females had mated and were characterized by mature or actively developing ovaries (R. N. Lipcius pers. obs.), and therefore serve as a surrogate for adult females during the reproductive period. Monthly mean weight of adult females per tow was calculated using monthly mean size per tow in the power function that described the size-weight relationship. Monthly values of mean spawning stock biomass were computed as the average of the product of crab weight and abundance per tow. We assumed that the residence time of females in the spawning grounds was constant between years (Prager 1996).

Size structure and mean size at maturity $\left(L_{\mathrm{m}}\right)$. The size structure of females on the spawning grounds was characterized in 2 ways. First, we graphed size frequencies and calculated the fractions of females in smaller size categories (i.e., $\mathrm{cw}<140$ and $<110 \mathrm{~mm}$ ). Second, we derived $L_{\mathrm{m}}$ (size at which $50 \%$ of females were mature) by calculating the mature fraction of all females (juveniles + adults) in the spawning grounds as a function of size, and estimating the inflection using the non-linear logistic regression:

$$
P_{i}=\frac{\alpha}{\left(1+\frac{\operatorname{size}}{L_{\mathrm{m}}}\right)^{\beta}}
$$

where the proportion of adult females per $10 \mathrm{~mm} \mathrm{cW}$ intervals was the dependent variable, size (in $\mathrm{mm} \mathrm{cw}$ ) was the independent variable, and $\alpha, \beta$, and $L_{\mathrm{m}}$ were parameters of the function. Estimates of $L_{\mathrm{m}}$ were correlated with spawning stock biomass, abundance and female size.

Larval and postlarval abundance. Given the relatively low proportion of zooplankton samples with nonzero values for larvae and postlarvae, we used monthly mean concentrations summed over the sampling stations (Table 1) in parametric analyses. We determined the internal consistency of continuous and discrete measures of larval and postlarval abundance by correlating the annual number of non-zero samples (discrete variable) with the annual mean concentration (continuous variable). For both larvae and postlarvae, these correlations were positive and highly significant (larvae: $\mathrm{r}^{2}=0.96$, df $=1,13, \mathrm{p}<0.0005$; postlarvae: $\mathrm{r}^{2}=$ 0.90 , df $=1,13, p<0.0005)$. We therefore concluded that it was appropriate to use the mean concentrations of larvae and postlarvae as measures of abundance in statistical analyses. Values were log-transformed (log $[100 x+1])$ to normalize the data and reduce heterogeneity of variance (Underwood 1997). In all cases, variances were either not heterogeneous (Cochran's $C$ statistic) or the $F$-test in analyses of variance was rejected at an alpha level lower than that used in the test for homogeneity of variance (Underwood 1997).

Larval and postlarval abundances did not exhibit a consistent pattern between years, such that high or low values occurred in all sampling months (paired $t$-tests, Bonferroni-adjusted $\mathrm{p}>0.05)$. For 2 missing sets of data points (June 1985, August 1998), we substituted the mean of the values for July in those years, and reduced the error degrees of freedom accordingly in the analysis of variance (Underwood 1997). In addition, there were 2 extreme outliers ( $>3 \mathrm{SD}$ of the mean) out of the 735 data points (1 before and 1 after 1991), which caused heterogeneous variances; these were replaced by the next highest values in the data set to equalize variances. Inter-relationships between larval abundance, postlarval recruitment, and spawning stock abundance were analyzed with non-linear regression using annual mean values for each phase. For the spawning stock $(S)$-recruitment $(R)$ and spawning stock-larval abundance relationships, a Beverton-Holt model was also analyzed using the non-linear regression:

$$
R=\frac{\alpha S}{\beta+S}
$$


We estimated larval production using the mean size and abundance data with a function describing the fecundity-size relationship for blue crab adult females (Prager et al. 1990):

$$
\frac{\text { Estimated larvae }}{\text { Female }}=(0.38 \cdot \text { Carapace width })-2.25
$$

which yields egg production in $10^{6}$ eggs using carapace width in centimeters. Mean monthly fecundity per female was calculated by the above equation and our monthly mean size. Then, we estimated larval production as the product of mean female abundance and mean fecundity per female.

\section{RESULTS}

\section{Abundance}

Adult female abundance in the spawning grounds varied significantly by year (Fig. 2a, ANOVA, $F=$ 16.89; df $=12,25$; $<$.0005). Annual abundances in 1988 to 1991 did not differ from each other, but these were significantly higher than those in 1992 to 2000, except in 4 of 36 comparisons; abundance was lower and relatively stable during 1992 to 2000 (Tukey's mul-

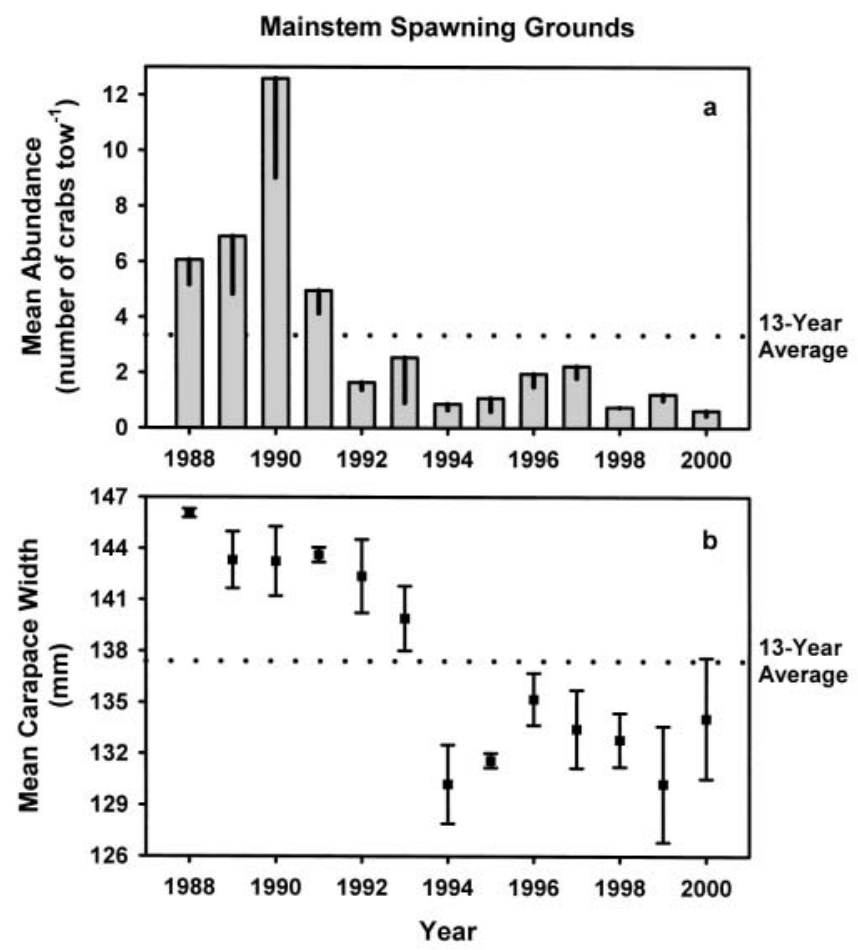

Fig. 2. Annual arithmetic mean abundance (a) and size (b) of adult females in Chesapeake Bay spawning grounds. Vertical bars $=1 \mathrm{SE}$

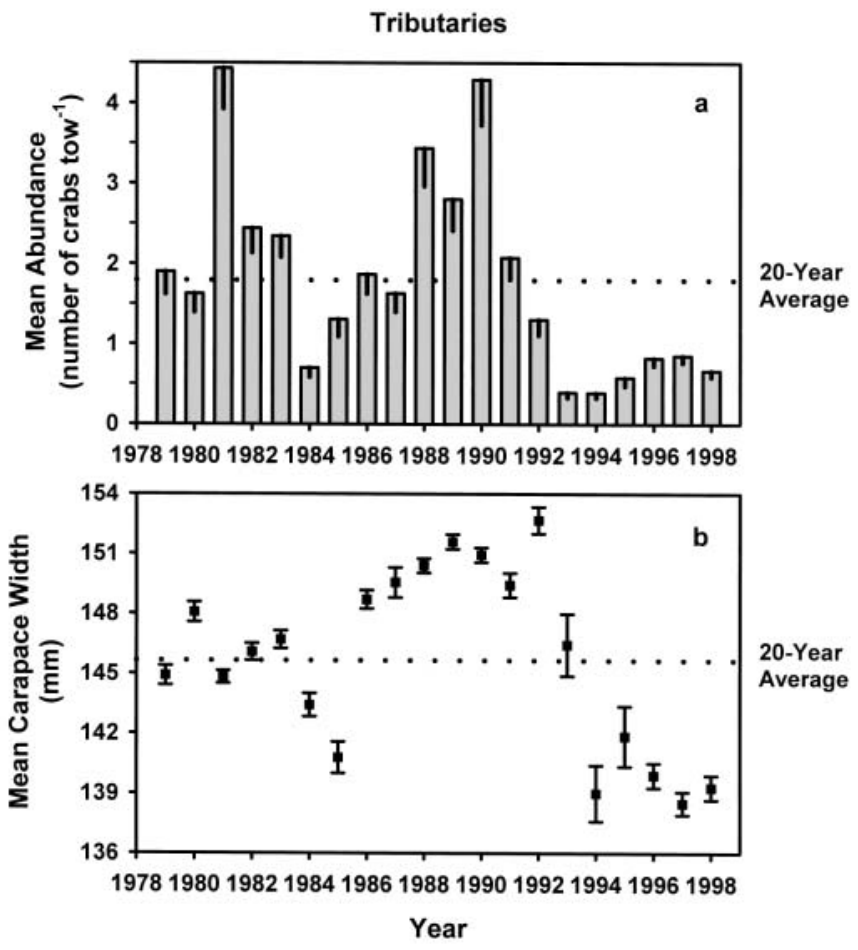

Fig. 3. Annual mean abundance (a) and mean size (b) of adult females in the tributaries (James, York and Rappahannock Rivers). Vertical bars $=1 \mathrm{SE}$

tiple comparisons, family $\alpha=0.05$, individual test $\alpha=$ 0.0012). The 4 non-significant comparisons involved 1991 with 1992, 1993, 1996, and 1997; 1991 seemed to be a transitional year in terms of abundance (Fig. 2a). Spawning stock abundance declined by $81 \%$ between 1988-1991 $($ mean $=7.63)$ and 1992-2000 $($ mean $=$ 1.43).

To determine whether the decline in spawning stock abundance was symptomatic of a long-term pattern, we examined abundance of adult females in the tributaries from 1979 to 1998 (Fig. 3a). Adult female abundances in the tributaries (Fig. 3a) and in the spawning grounds (Fig. 2a) correlated significantly (Fig. 4). We used the relationship between abundance of adult females in the tributaries and spawning grounds to extend the historical pattern of spawning stock abundance back to 1979. Examining the data in this historical context, the low numbers of adult females during 1992 to 2000 represent at least a 20 yr minimum.

\section{Size}

The mean size of adult females varied significantly by year (Fig. 2b, ANOVA, $F=7.96$; df $=12,25$; p < 0.0005). In comparisons between years (Tukey's multi- 


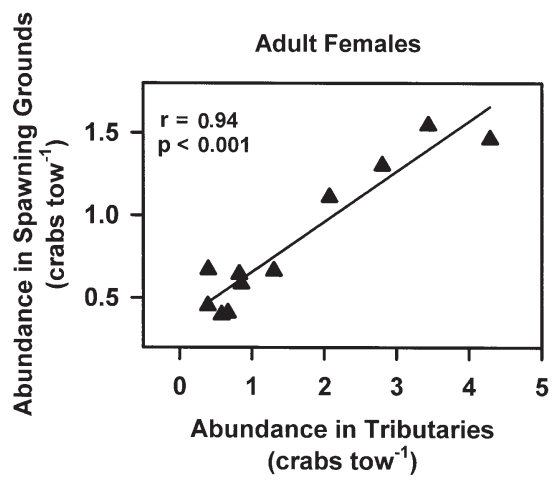

Fig. 4. Correlation between mean abundances of adult females in Chesapeake Bay spawning grounds and tributaries (James, York and Rappahannock Rivers) from 1989 to 1998

ple comparisons, family $\alpha=0.05$, individual test $\alpha=$ 0.0012), sizes from 1988 to 1991 were significantly larger than those from 1994 to 2000 in most comparisons. Size in 1992 was only greater than 3 of the 7 years from 1994 to 2000, while size in 1993 was transitional and not significantly different from size in any year. Mean size in the spawning grounds decreased by 8\% between 1988-1991 (mean $=144.1 \mathrm{~mm} \mathrm{cw})$ and $1994-2000$ (mean $=132.5 \mathrm{~mm}$ cw). Similarly, mean size in tributaries (Fig. 3b) decreased by $5 \%$ between 1979-1991 $($ mean $=147.3 \mathrm{~mm} \mathrm{cw})$ and 1994-1998 $($ mean $=139.7 \mathrm{~mm} \mathrm{cw})$.

\section{Correlation of abundance and size}

The mean size and abundance of adult females in the spawning grounds were significantly and positively correlated (Fig. 5a: $\mathrm{r}^{2}=0.73$; df $=2,10 ; \mathrm{p}=$ $0.0015)$. In addition, the relationship was asymptotic at approximately $146 \mathrm{~mm}$ cw. Similarly, the mean size and abundance of adult females in the tributaries correlated significantly and positively (Fig. $5 \mathrm{~b}: \mathrm{r}^{2}=0.44$; $\mathrm{df}=2,17 ; \mathrm{p}=0.0075)$, with an upper asymptote of approximately $150 \mathrm{~mm} \mathrm{cw}$.

\section{Weight and biomass}

Weight (g) of adult females was significantly related to size (mm cw) by a power function (Fig. 6: $\mathrm{r}^{2}=0.87$, $\mathrm{df}=1,387 ; \mathrm{p}<.001$ ). Spawning stock biomass was calculated as the product of weight and abundance, and compared with the interannual pattern of abundance in the spawning grounds (Fig. 2a). Spawning stock biomass and abundance were highly correlated (leastsquares linear regression, $\mathrm{r}^{2}=0.998, \mathrm{df}=1,11$; $\mathrm{p}<$ 0.0001 ), precluding the need to represent both mea- sures of the spawning stock. The interannual pattern in spawning stock biomass mirrored that for abundance (Fig. 2a), and displayed an $84 \%$ reduction in mean spawning stock biomass from $1047 \mathrm{~g} \mathrm{tow}^{-1}$ between 1988 and 1991 to $166 \mathrm{~g} \mathrm{tow}^{-1}$ between 1994 and 2000.

(a) spawning grounds

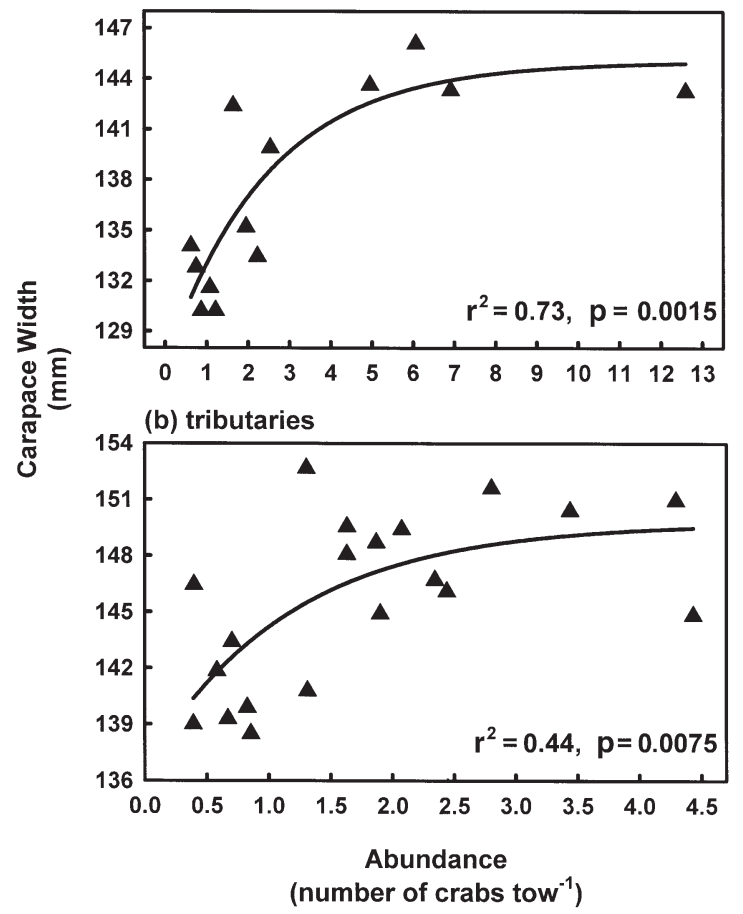

Fig. 5. Correlation between mean size and abundance of adult female blue crabs in (a) Chesapeake Bay spawning grounds from 1988 to 2000, and (b) tributaries (James, York and Rappahannock Rivers) from 1979 to 1998. Function for the spawning grounds is $y=127.1+18.0\left(1-\mathrm{e}^{-0.40 x}\right)$, and for the tributaries $y=136.6+13.2\left(1-\mathrm{e}^{-0.86 x}\right)$

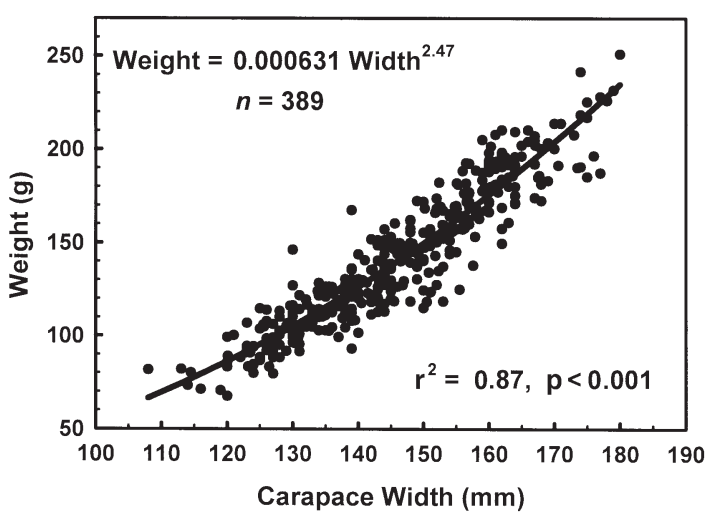

Fig. 6. Relationship between size and weight of adult females in Chesapeake Bay during winter. Females are characterized by nearly ripe or developing ovaries, and therefore serve as a surrogate for adult females during the reproductive period 


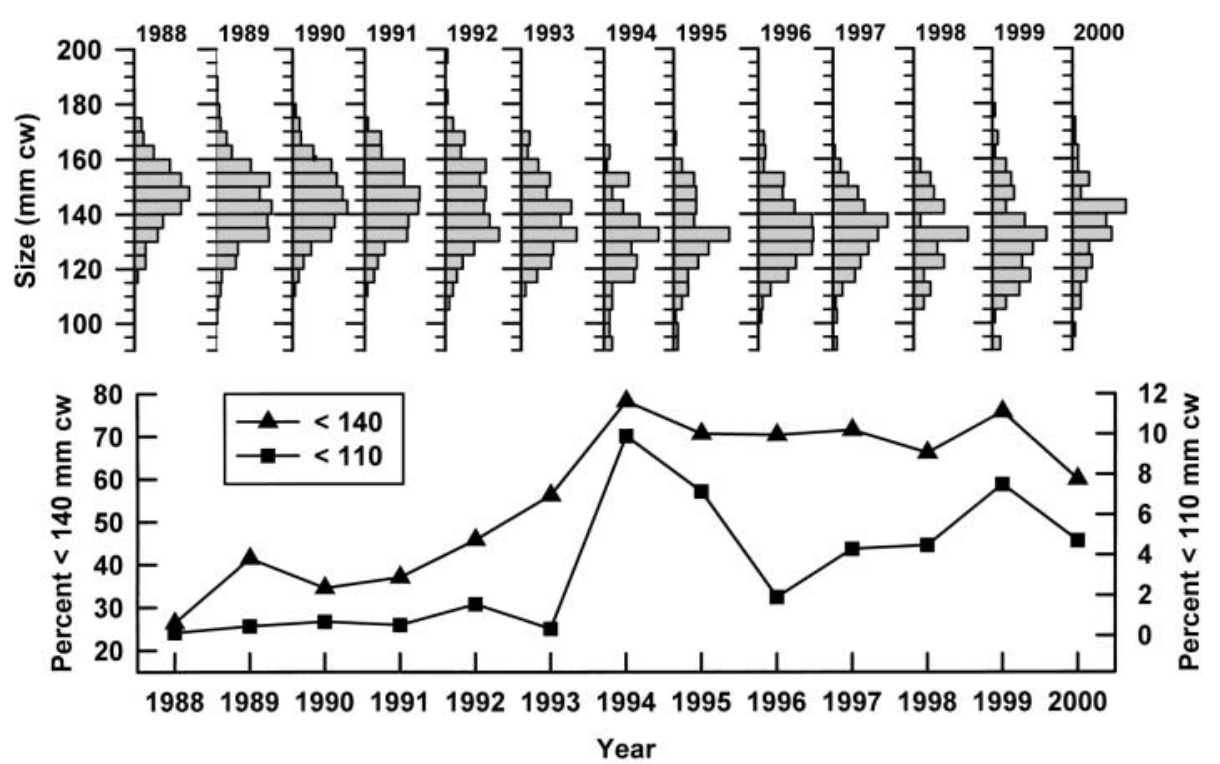

Fig. 7. Size structure of adult females and percentages of small adult females in the Chesapeake Bay spawning grounds from July to September, 1988 to 2000. cw: carapace width

\section{Size structure and mean size at maturity $\left(L_{\mathrm{m}}\right)$}

There was a distinct reduction in the mean size of adult females in the spawning grounds between 1992 and 1994 (Fig. 7). The proportion of adult females less than average size ( $<140 \mathrm{~mm} \mathrm{cw})$ doubled, increasing from 0.35 between 1988 and 1991 to 0.70 between 1994 and 2000 (Fig. 7). The proportion of small adult females $(<110 \mathrm{~mm} \mathrm{cw})$ increased dramatically, from 0.005 between 1988 and 1991 to 0.057 between 1994 and 2000 (Fig. 7). This alteration in size structure was reflected in the appearance of smaller adult females in the 80 to $110 \mathrm{~mm} \mathrm{cw}$ size range, and in the loss of larger adult females greater than $140 \mathrm{~mm} \mathrm{cw}$ (Fig. 7). Mean size at maturity $\left(L_{\mathrm{m}}\right)$ decreased $9 \%$ from approx-

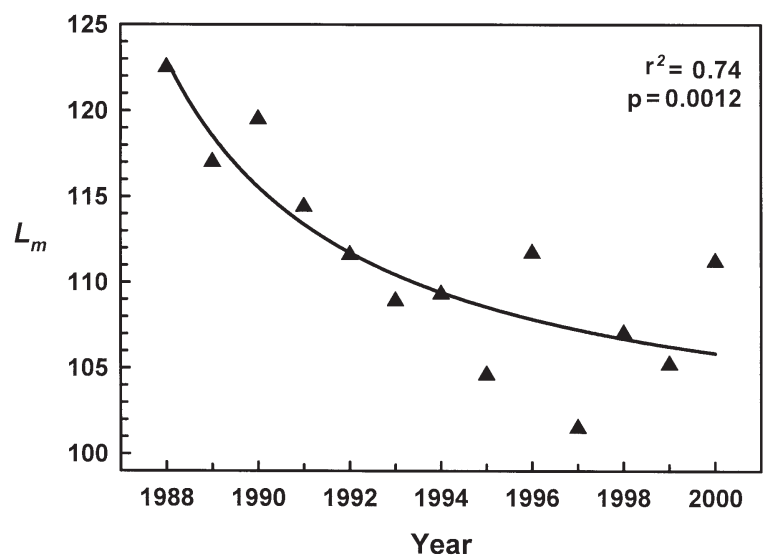

Fig. 8. Annual mean size at maturity $\left(L_{\mathrm{m}}, \mathrm{mm}\right.$ carapace width) of adult female blue crabs in the Chesapeake Bay spawning grounds. Function between mean size at maturity and time is $y=99.8\left(\mathrm{e}^{0.99 /(x-1983)}\right)$ imately $118.4 \mathrm{~mm} \mathrm{cw}$ between 1988 and 1991 to $107.9 \mathrm{~mm}$ cw between 1992 and 2000 (Fig. 8: $\mathrm{r}^{2}=0.74$, $\mathrm{df}=2,10 ; \mathrm{p}=0.0012$ ). Mean size at maturity also covaried significantly with spawning stock biomass (Fig. 9a: $\mathrm{r}^{2}=0.61, \mathrm{df}=2,10 ; \mathrm{p}=0.009$ ), female size (Fig. 9b: $\mathrm{r}^{2}=$ $0.68, \mathrm{df}=1,11 ; \mathrm{p}=0.0005$ ), and spawning stock abundance (Fig. 9c: $\mathrm{r}^{2}=0.57 ; \mathrm{df}=2,10 ; \mathrm{p}=0.014$ ).

\section{Larval and postlarval abundance}

Larval abundance in the spawning grounds varied significantly by year (Fig. 10a, ANOVA, $F=5.74 ; \mathrm{df}=$ $14,45 ; \mathrm{p}<0.0005)$. We tested the main conclusion derived from the results for spawning stock abundance, specifically that larval abundance between 1985 and 1991 would be greater than that between 1992 and 1999, which was confirmed (ANOVA, $F=$ 65.19; $\mathrm{df}=1,13 ; \mathrm{p}<0.0005$ ). Larval abundance was an order of magnitude higher between 1985 and 1991 than between 1992 and 1999 (Fig. 10a).

Given the very high proportion of zero data points for postlarval abundance, we did not analyze postlarval abundance using monthly data. Instead, we used the annual means to test the hypothesis that postlarval abundance between 1985 and 1991 was greater than between 1992 and 1999 (Fig. 10b), because the annual means (1) were approximately normally distributed, and (2) did not suffer from heterogeneous variances (Levene's test, $\mathrm{p}=0.329$ ). To assess the consistency of the results, we also tested this hypothesis using the number of annual non-zero samples, which correlated with the abundance data (see 'Methods') and also did not display heterogeneous variances (Levene's test, $\mathrm{p}=$ 0.722). In both cases, postlarval abundance was signif- 
icantly higher between 1985 and 1991 than between 1992 and 1999 (Fig. 10b, ANOVA, postlarval abundance: $F=10.26 ; \mathrm{df}=1,13 ; \mathrm{p}=0.007$, number of nonzero samples: $F=14.20 ; \mathrm{df}=1,13 ; \mathrm{p}=0.002$ ).

\section{Spawning stock, larval abundance, and postlarval recruitment}

Larval abundance (Fig. 10a) was significantly and positively correlated with the spawning stock (Fig. 2a), both in the spawning grounds and in the tributaries (Fig. 11, Table 3). Since fecundity scaled linearly with female size (see 'Methods'), the relationship between
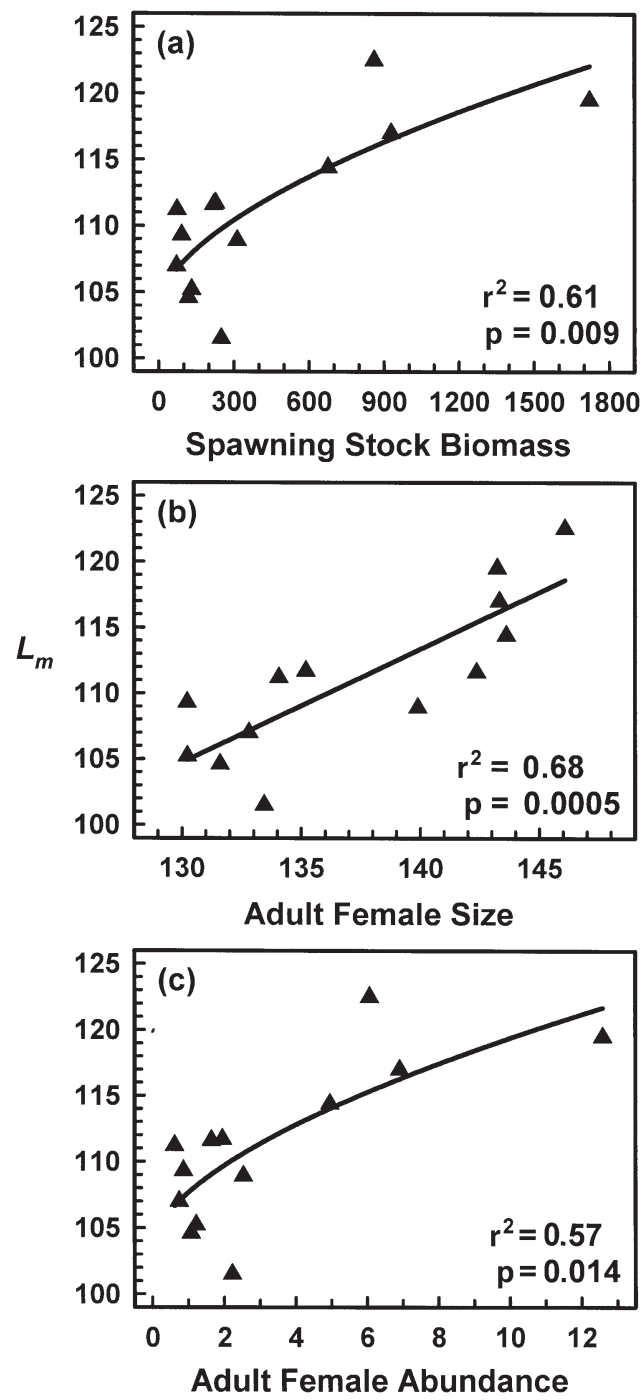

Fig. 9. Correlation between mean size at maturity $\left(L_{\mathrm{m}}, \mathrm{mm}\right.$ carapace width) and (a) spawning stock biomass $(y=104.0+$ $\left.0.22 x^{0.59}\right)$, (b) adult female size $(y=-7.49+0.86 x)$, and (c) spawning stock abundance $\left(y=103.6+4.0 x^{0.59}\right)$, in Chesapeake Bay spawning grounds from 1988 to 2000
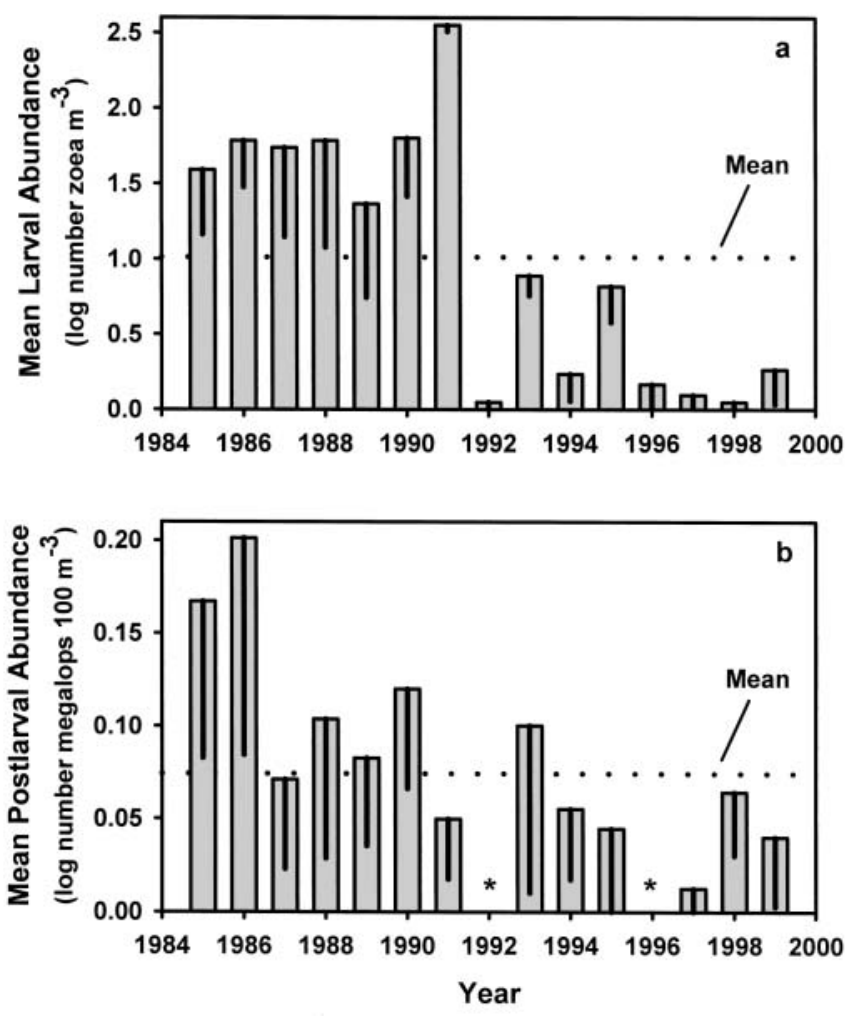

Fig. 10. Annual larval abundance (a) and postlarval abundance (b) measured as mean of the monthly log-transformed concentrations $(100 x+1)$ per $\mathrm{m}^{3}$ from lower bay stations (Table 1 ). Vertical bars $=1 \mathrm{SE}$. * Zero values (samples taken as

in other years, but no larvae or postlarvae present)

predicted larval abundance (based on egg production) and observed larval abundance was equivalent to that between larval abundance and spawning stock abundance (Fig. 11a).

Postlarval recruitment also correlated significantly and positively with spawning stock abundance in the spawning grounds (Fig. 12, Table 3). The degree of association with the spawning stock diminished between the larval $\left(\mathrm{r}^{2}=0.63\right)$ and postlarval $\left(\mathrm{r}^{2}=0.35\right)$ stages. Postlarval recruitment correlated significantly and positively with larval abundance, whether with or without 1 outlier for postlarval recruitment (Fig. 13). The outlier for recruitment occurred during 1991 (Fig. 13), when spawning stock abundance (Fig. 2a) and larval abundance (Fig. 10a) were high, yet postlarval recruitment was lower than the long-term average (Fig. 10b).

We also examined the relationships between larval or postlarval abundance and the subsequent spawning stock lagged in the future 1 or 2 yr (Fig. 14). Although the relationships using both lags were similar, those lagged by 1 yr displayed the lowest variability and are presented herein (Fig. 14). There were no significant 
(a) spawning grounds

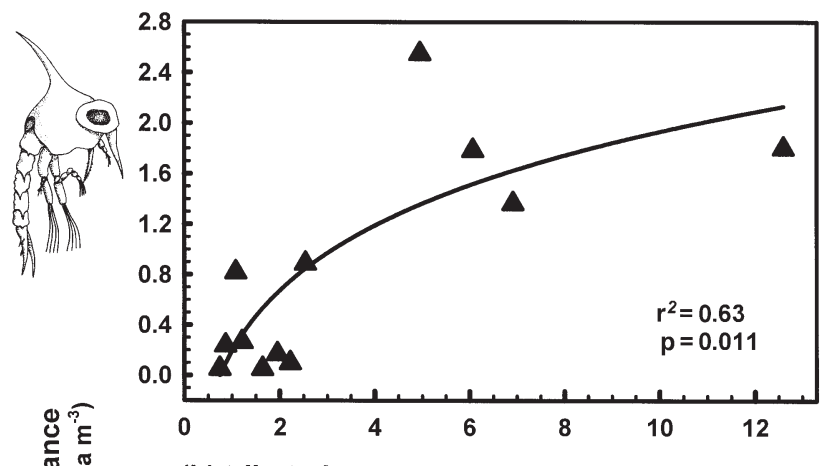

(b) tributaries

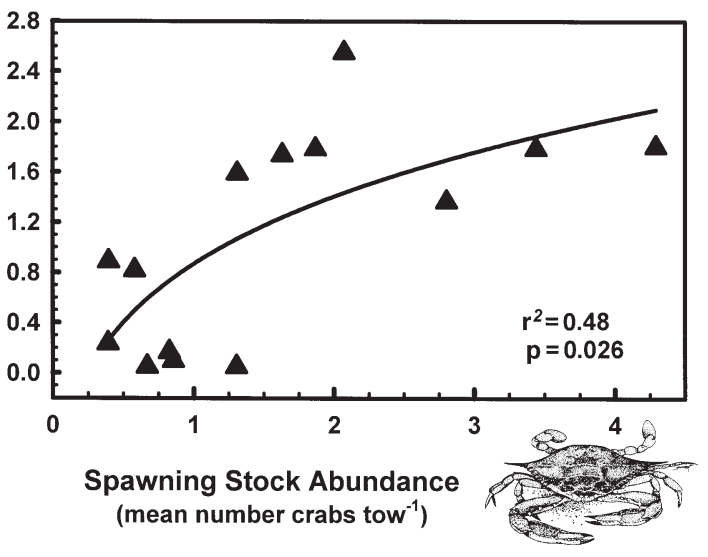

Fig. 11. Relationships between larval abundance and spawning stock abundance in spawning grounds (a) and tributaries (b). Values are annual means (Figs 2a, 3a \& 10a). Larval abundance correlated significantly and positively with spawning stock abundance in the spawning grounds (a: $y=$ $-6.15+6.34 x^{0.11}$, Table 3 ) and in the tributaries (b: $y=-2.53+$ $3.40 x^{0.21}$, Table 3$)$. The fit of the Beverton-Holt model $[y=$ $(3.68 x) /(9.05+x)$, Table 3$]$ to the spawning stock-larval abundance relationship in the spawning grounds was nearly equivalent to the power function (a), but displayed nonrandom residuals so the power function was retained. (Crab illustrations by K. Forrest) regression models that adequately fit the relationships between larval (Fig. 14a) or postlarval (Fig. 14b) abundance and the subsequent spawning stock (non-linear regression, $\mathrm{p}>0.2$ ), although there was a distinct association between both measures of recruitment and the spawning stock (Fig. 14). Except for the indicated single outliers in each relationship, all high values for the abundance of larvae, postlarvae, and the spawning stock were from 1985 to 1991, whereas all low values were from 1992 to 2000 (Fig. 14), suggesting an abrupt transition between high and low phases in abundance

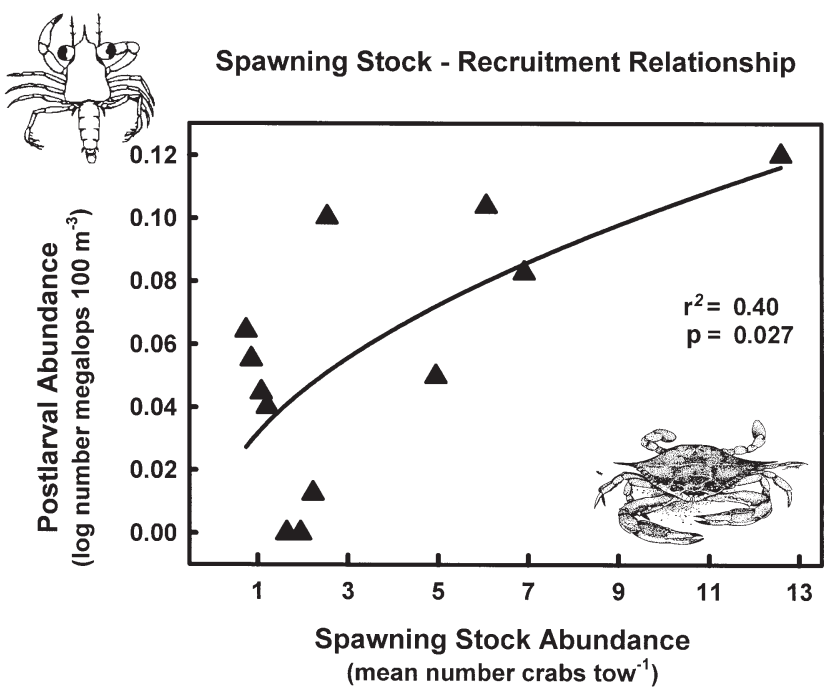

Fig. 12. Relationship between postlarval recruitment and spawning stock abundance in spawning grounds. Values are the annual means (Figs 2a \& 10b). Postlarval recruitment correlated significantly and positively with spawning stock abundance (Beverton-Holt model: $[y=(0.16 x) /(5.63+x)]$, Table 3). Relationship between postlarval recruitment and spawning stock biomass, rather than abundance, was nearly equivalent in form and significance (Table 3). (Crab illustrations by K. Forrest)

Table 3. Callinectes sapidus. Non-linear regression analyses for the relationships of larval abundance and postlarval recruitment with spawning stock abundance. SSA: spawning stock abundance; SSB: spawning stock biomass. All analyses used SSA and SSB in the spawning grounds, except for SSA-larval abundance (tributaries), which used abundance of adult females in the 3 tributaries (James, York, and Rappahannock Rivers) as SSA. Power functions were of the form $y=\alpha x^{\beta}$ or $y=\delta+\alpha x^{\beta}$; the BevertonHolt model was of the form $y=\alpha x /(\beta+x)$

\begin{tabular}{|c|c|c|c|c|}
\hline Relationship & Model & $\mathrm{r}^{2}$ & df & $\mathrm{p}$ \\
\hline \multirow[t]{2}{*}{ SSA-larval abundance } & Power function & 0.63 & 2,9 & 0.011 \\
\hline & Beverton-Holt & 0.62 & 1,10 & 0.002 \\
\hline SSA-larval abundance (tributaries) & Power function & 0.48 & 2,11 & 0.026 \\
\hline SSB-larval abundance & Beverton-Holt & 0.65 & 1,10 & 0.002 \\
\hline \multirow[t]{2}{*}{ SSA-postlarval recruitment } & Power function & 0.40 & 1,10 & 0.027 \\
\hline & Beverton-Holt & 0.35 & 1,10 & 0.043 \\
\hline \multirow[t]{2}{*}{ SSB-postlarval recruitment } & Power function & 0.39 & 1,10 & 0.030 \\
\hline & Beverton-Holt & 0.32 & 1,10 & 0.057 \\
\hline
\end{tabular}


Larval Abundance - Postlarval Recruitment

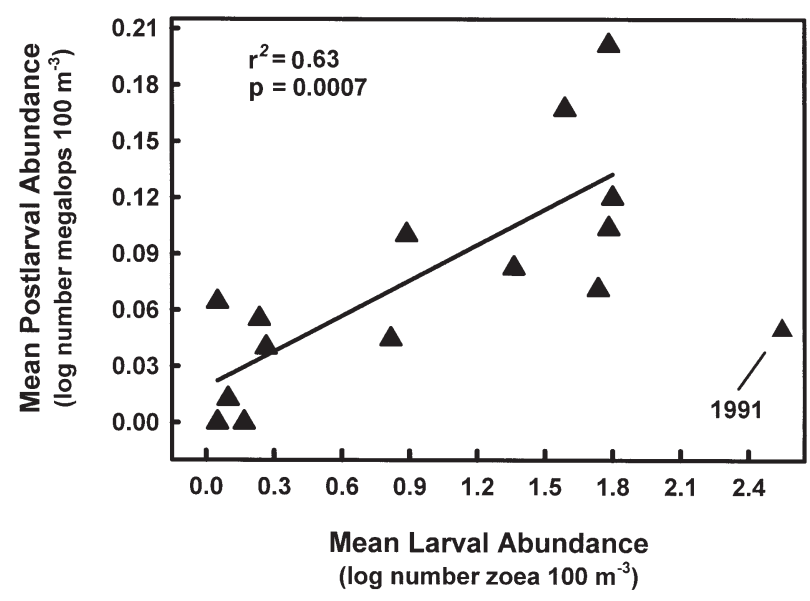

Fig. 13. Relationship between postlarval recruitment and larval abundance in lower bay. Values are annual means (Fig. 10). Postlarval recruitment correlated significantly and positively with larval abundance, whether without $(y=$ $\left.0.019+0.063 x, \mathrm{r}^{2}=0.63, \mathrm{df}=1,12, \mathrm{p}=0.0007\right)$ or with $(y=$ $\left.0.031+0.043 x, r^{2}=0.38, d f=1,13, p=0.014\right)$ the 1991 outlier for recruitment. Regression line shown is without the outlier, although regression line with the outlier was similar

rather than proportional relationships between recruitment and the spawning stock. The single outlier in the larval abundance-spawning stock relationship was in 1991 (Fig. 14a), when larval abundance was high (Fig. 10a), but subsequent spawning stock abundance was low (Fig. 2a) after poor postlarval recruitment in 1991 and 1992 (Fig. 10b). The single outlier in the postlarval recruitment-spawning stock relationship was in 1993 (Fig. 14b), when postlarval recruitment was high (Fig. 10b), but subsequent spawning stock abundance was low (Fig. 2a).

\section{DISCUSSION}

Over the past decade, the blue crab population in Chesapeake Bay has endured a concurrent, persistent and substantial reduction in the spawning stock, postlarval recruitment, larval abundance, female size, and size at maturity. The decrease in these variables was rapid and occurred over 1 to $2 \mathrm{yr}$, which is indicative of a phase shift in the spawning stock and recruitment, rather than a progressive diminution. In addition, the relationships between spawning stock abundance (SSA) and larval abundance, SSA and postlarval recruitment, and SSA and female size were positive and significant. Although prior investigations with marine invertebrates have shown decreases or associations in some variables (Levitan 1991, Grosberg \& Levitan 1992, Hilborn \& Walters 1992, Peterson \& Sum-

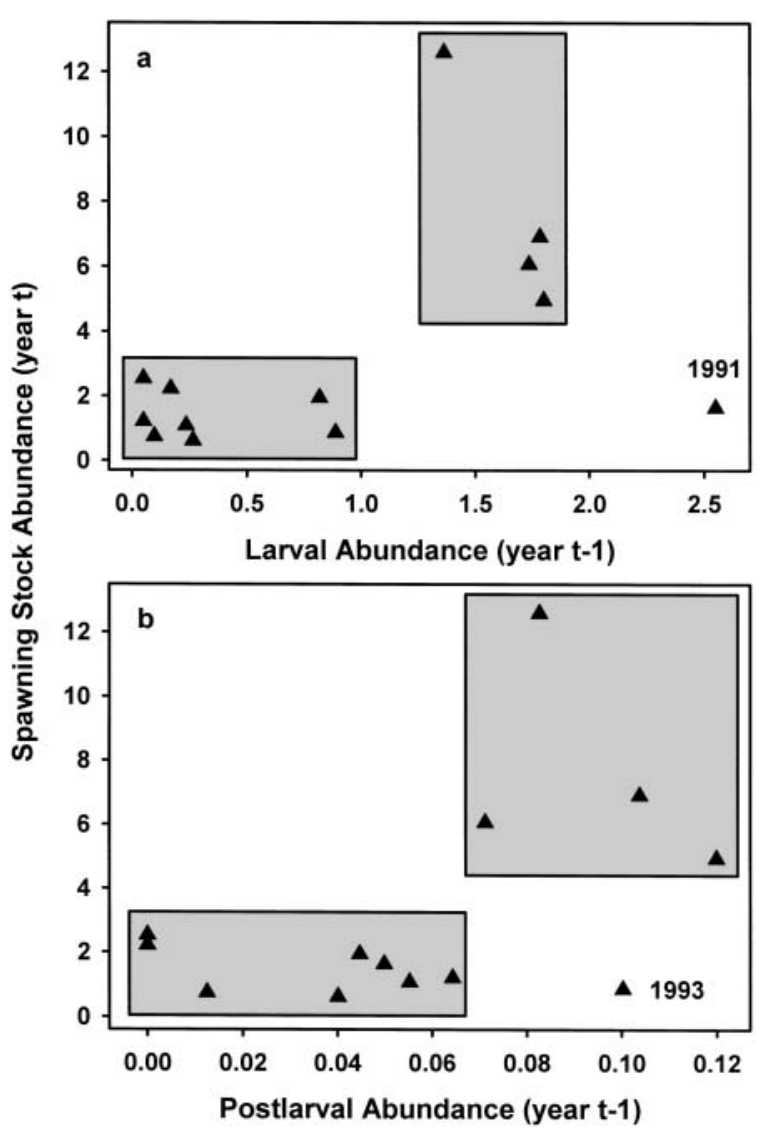

Fig. 14. Relationships between larval abundance (a) or postlarval recruitment (b) in Year $t-1$ and spawning stock abundance during Year $t$ in the spawning grounds. There were no significant non-linear regressions between larval abundance or recruitment and subsequent spawning stock due to stepwise nature of the relationships. Shaded boxes encompass periods of high or low recruitment and abundance, except for the 2 outliers (1991 for larval abundance, and 1993 for postlarval recruitment)

merson 1992, Caputi et al. 1995, Eckman 1996, Garcia 1996, Honkoop et al. 1998, Hughes et al. 2000), these findings are unique in that they demonstrate a nearsimultaneous decrease and significant association in all these variables. Covariation in these population characteristics merits further investigation in crustaceans and other marine invertebrates, especially concerning the implications of a reduced spawning stock and recruitment for conservation and sustainable exploitation.

\section{Simultaneous decrease in spawning stock abundance, recruitment, and female size}

The depression of the blue crab spawning stock in Chesapeake Bay during 1992 to 2000 was significant in both magnitude (81\%) and duration, which so far has 
included a 9 yr period through 2000. At the same time, a comparable baywide reduction ( $70 \%)$ has occurred in blue crab population size, as measured independently in winter by a dredge survey of all $1+$ males and females (Lipcius et al. 2002a). We believe that these reductions reflect a substantial and persistent erosion of the spawning stock, recruitment, and the population. Furthermore, fishing mortality rates are at or near overexploitation (Miller \& Houde 1998) and are depensatory (Lipcius et al. 2002a), indicating a need to scrutinize the sustainability of current fishery exploitation rates.

The decline in spawning stock and recruitment was not progressive, but rather a shift from a higher level in 1979 to 1991 to a lower level in 1992 to 2000. Such a sizeable and lasting downturn is uncommon for the blue crab. Although crab abundance fluctuates greatly, often with rapid drops or ascents (Jones et al. 1990, Lipcius \& Van Engel 1990, Abbe \& Stagg 1996, Rugolo et al. 1998), the extended decrease in the spawning stock and recruitment since 1992 appears unique, and is similar to patterns characterizing populations that have experienced a phase shift (Steele \& Henderson 1984, Hilborn \& Walters 1992, Hughes 1994, Holbrook et al. 1997, Hughes \& Tanner 2000). Comparable phase shifts have occurred in diverse taxa, including temperate reef fish (Holbrook et al. 1997), sea urchins and corals (Hughes 1994, Hughes \& Tanner 2000), and pelagic fish (Steele \& Henderson 1984, Hilborn \& Walters 1992).

We propose that the cause of the decrease was poor recruitment in 1991, despite high spawning stock and larval abundance, and that this poor recruitment, in concert with high fishing and natural mortality, subsequently led to a diminished spawning stock in 1992. Thereafter, the spawning stock, larval abundance and recruitment have remained at low levels, except for 1 year in 1993 when recruitment was high, but the subsequent spawning stock and larval abundance remained low, probably due to high fishing and natural mortality. The mechanism producing poor recruitment in 1991 has not been identified, although it probably involved an alteration in environmental or biotic conditions necessary for successful larval survival and reinvasion of the Bay by postlarvae from the continental shelf. In the case of other population phase shifts, the postulated mechanisms have included stochastic environmental variation (Steele \& Henderson 1984), disease, catastrophic disturbance and overfishing (Hughes 1994, Hughes \& Tanner 2000), and altered climate regimes and primary productivity (Holbrook et al. 1997). We further suggest that the spawning stock, larval abundance, and recruitment are unlikely to rebound to former high levels without significant reductions in fishing and natural mortality along with - enhanced environmental conditions conducive to successful recruitment.

\section{Consequences of reduced spawning stock abundance, recruitment, and female size}

Two key consequences of a small spawning stock are the increased probability of a diminished supply of recruits to the population, and reduced resilience to demographic and environmental stochasticity (Hilborn \& Walters 1992). Given appreciable drops in larval production, the likelihood of recruitment failure is heightened, particularly when the population decrease persists more than a few years. In concert with high exploitation rates during decline (Miller \& Houde 1998, Rugolo et al. 1998, Lipcius et al. 2002a), the probability of recruitment overfishing is exacerbated, even in a resilient species such as the blue crab (M. Fogarty pers. comm.), which can hatch an average of 3.2 million eggs per egg mass (Prager et al. 1990) at least 1 to 2 times annually (Jones et al. 1990). Heavy exploitation and degraded environmental conditions can drive even the most fecund of species either to collapse or to a lower population level (Steele \& Henderson 1984, Hilborn \& Walters 1992, Hughes 1994, Holbrook et al. 1997).

The impact of covariation in female size and spawning stock abundance upon population persistence depends on the underlying mechanism (i.e., genetic, phenotypic or size-selective exploitation). If size-selective exploitation underlies the covariation, then the pattern in covariation is symptomatic of a depensatory process (i.e., inversely density-dependent), whereby the recovery potential of a reduced population is further lessened at low population abundance. Depensatory mortality exacts a proportionally higher mortality at low population abundance, which increases the likelihood of local extinction and population collapse (Hassell 1978, Hilborn \& Walters 1992). In blue crabs, larval production of the spawning stock is decreased disproportionately to population abundance due to the simultaneous reduction in adult female size and fecundity. Reduced female or male size may also have minimized mating opportunities with appropriately sized mates, and thus lowered fertilization rates (Smith \& Jamieson 1991, Abbe \& Stagg 1996, Jamieson et al. 1998).

Alternatively, compensatory fecundity during periods of low abundance could offset the impact of a diminished spawning stock (J. McConaugha pers. comm.). Using published information, we examined the likelihood of a compensatory increase in sizespecific fecundity at low abundance by calculating size-specific fecundity during $2 \mathrm{yr}$ when population 
abundance varied significantly. We used empirical estimates of size-specific fecundity in 1986 and 1987 (Prager et al. 1990), for which 1 year (1987) had a 60 to $71 \%$ reduction in spawning stock abundance (Jones et al. 1990), which is comparable to that which we observed. In 1987, when spawning stock abundance was low, size-specific fecundity was $1.33 \times 10^{6}$ eggs higher than in 1986 when abundance was high, which is consistent with the compensation hypothesis. Using this information, we estimated that fecundity was $2.5 \times$ $10^{6}$ eggs female ${ }^{-1}$ for 1988 to 1991 (fecundity $=-2.92+$ 0.38 [carapace width]) when the average size was about $144 \mathrm{~mm} \mathrm{cw}$, and $3.4 \times 10^{6}$ eggs female ${ }^{-1}$ for 1994 to 2000 (fecundity $=-1.59+0.38$ [carapace width]) when the average size was $133 \mathrm{~mm} \mathrm{cw}$. The product of these values and the corresponding abundances yielded estimates of the decrease in larval production as 81 to $85 \%$ without compensation and $75 \%$ with compensation. Thus, even with a compensatory response, larval production would drop substantially due to the dominant effect of reduced abundance on the spawning stock.

\section{Potential mechanisms of covariation in female size and abundance}

\section{Genetic alterations}

Reduction in female size with increasing blue crab abundance may have resulted from directional selection of demographic characters such as $L_{\mathrm{m}}$, or proportionally greater increases in larval survival and recruitment of the offspring of smaller adult females. In recent years when the stock was at low abundance, the percentage of the spawning stock composed of smaller adult females (e.g., $<140 \mathrm{~mm} \mathrm{cw}$ ) rose from 35 to $70 \%$. Adult females of 80 to $100 \mathrm{~mm}$ cw were rare when the spawning stock was high in 1988 to 1991, but much more common from 1992 to 2000 when the spawning stock was low. Females may have matured at a younger age and smaller size to optimize mating opportunities when larger potential mates were sparse (Smith \& Jamieson 1991, Jamieson et al. 1998) or to maximize lifetime reproductive output when matecompetition with other adult females was low (Lipcius 1985).

A genetic basis for covariation between female size and abundance could have resulted from directional selection (Policansky 1993) due to size-selective exploitation of large females (Jamieson 2001) or to a lifehistory response at low abundance (Charnov et al. 1978, Charnov 1979, Hannah \& Jones 1991, Wellborn 1994, Sparkes 1996). Size-selective exploitation might have increased the relative contribution of smaller females to subsequent generations (Jamieson 2001), whereas a life-history response may have involved various compensatory responses such as decreases in the mean size, age, or instar at maturity (Charnov et al. 1978, Charnov 1979, Hannah \& Jones 1991, Wellborn 1994, Sparkes 1996). For instance, protandrous pandalid shrimp apparently responded to heavy exploitation by lowering the age at which males become females (Charnov et al. 1978, Charnov 1979). Freshwater amphipods reduced mean adult size and size at maturity at high predation rates, while concurrently increasing size-specific reproductive investment, and thereby compensating for reduced female size (Wellborn 1994). In pink shrimp (Pandalus jordani), the fraction of younger shrimp that matures was inversely proportional to population abundance; younger adults may have increased size-specific fecundity as a compensatory response to low abundance (Hannah \& Jones 1991). Although genetic selection has been demonstrated in some crustaceans, primarily short-lived planktonic species (e.g., Gliwicz \& Rykowska 1992, see review by Jamieson 2001), it has not been documented for longer-lived, larger species such as lobsters and crabs (Jamieson 2001). In the blue crab, the rapid alteration in size and the lack of significant covariation between female size and abundance in the middle and upper portions of Chesapeake Bay (Uphoff 1998), which is outside the spawning grounds, are inconsistent with a genetic mechanism.

\section{Phenotypic plasticity}

Phenotypic plasticity involves responses to environmental or biotic conditions by temporary and rapid alterations of specific vital rates or demographic variables (Pollock 1995). In contrast to a genetic alteration, phenotypic plasticity is usually of short duration (i.e., no less than years to decades) and reversible. For example, $L_{\mathrm{m}}$ and growth rate were inversely related to population abundance in the western rock lobster Panulirus cygnus, most probably due to intraspecific competition for food (Chittleborough 1976, 1979).

Covariation in female size and abundance of the blue crab may have been due to phenotypic plasticity in demographic variables when the population was heavily exploited and therefore at low spawning stock abundance. Proximate cues such as a low abundance of adult females (i.e., competitors for mates) or of sufficiently large males (i.e., potential mates) may have stimulated immature females to initiate their pubertal molt at an earlier age or instar (Polovina 1989, Jamieson et al. 1998), and therefore at a smaller adult size. In addition, a population at low abundance may have greater per capita food availability, which can 
either accelerate sexual development and stimulate sexual maturity at a smaller size (Rothschild 1986), or increase the size-specific fecundity of females (Hannah \& Jones 1991, Wellborn 1994). In contrast, enhanced food availability may increase growth rates and $L_{\mathrm{m}}$, if $L_{\mathrm{m}}$ is determined by age or the number of instars to maturity (Hartnoll 1985). Such plasticity in reproductive and growth patterns is common in other decapod crustaceans (Lipcius 1985), and may be adaptive given variable abundances of mature males and females.

Covariation between female size and abundance, the increase in the fraction of the spawning stock composed of smaller adult females in 1992 to 2000, and the compensatory increase in size-specific fecundity were consistent with a phenotypic response to low abundance. However, the absence of covariation between female size and abundance elsewhere in the bay (Uphoff 1998) was inconsistent with a mechanism involving phenotypic plasticity. The role of phenotypic plasticity in the covariation of female size and abundance remains unresolved.

\section{Size-selective exploitation}

Size-selective exploitation, usually of larger individuals, may alter demographic variables and vital rates rapidly without a genetic foundation (Jamieson 2001). For instance, the smaller size of adult male blue crabs in the middle and upper reaches of Chesapeake Bay (Abbe \& Stagg 1996) probably resulted from fishery removal of large males. For female blue crabs, sizeselective exploitation in combination with a terminal molt to maturity probably contributed significantly to the decrease in $L_{\mathrm{m}}$ and mean size. A terminal molt to maturity produces a relatively stable size distribution across age classes, so that alterations in size structure due to growth after maturity are precluded. Size-selective exploitation of larger females has been facilitated since 1994 through the use of cull rings (i.e., sizespecific escape gaps) in crab traps throughout the lower Chesapeake Bay and its tributaries, and in the upper and middle portions of the Bay outside the tributaries (R. O'Reilly, Virginia Marine Resources Commission, and H. Speir, Maryland Department of Natural Resources, pers. comm.). The typical cull ring allows many smaller adult females (i.e., $<140 \mathrm{~mm} \mathrm{cw}$ ) to escape, while concurrently retaining a higher fraction of larger individuals (Guillory \& Hein 1998). Under intensive exploitation, a greater proportion of smaller adult female blue crabs would escape crab traps and constitute the spawning stock, producing both a smaller $L_{\mathrm{m}}$ and mean size of adult females in the spawning grounds. Furthermore, $L_{\mathrm{m}}$ and mean size of adult females did not correlate with abundance in the tributaries of the upper and middle Chesapeake Bay (Uphoff 1998), where crab traps were prohibited and cull rings were not in use. In the same middle region of Chesapeake Bay, but in the mainstem where traps with cull rings have been used since 1994, female size and abundance correlated positively (Abbe \& Stagg 1996), as observed on the spawning grounds. Conversely, small adult female size co-occurred with low population abundance in 2 years between 1979 and 1988 before the extensive use of cull rings, suggesting phenotypic plasticity in demographic characters. We conclude that release of smaller adult females by cull rings is at least partly responsible for the reduction in female size with spawning stock abundance, although the benefit of increased escapement of mature females outweighed the negative effect of a reduction in female size upon spawning stock larval production. A combination of genetic, phenotypic and size-selective exploitation mechanisms probably acted in concert to produce covariation in female size and abundance of the blue crab spawning stock.

\section{Conservation of the blue crab spawning stock}

The utility of marine protected areas in sustaining renewable resources is acknowledged worldwide, and viewed as one of the most powerful management tools for conserving exploited species (Botsford et al. 1997, Roberts 1997, Allison et al. 1998, Guenette et al. 1998). The blue crab spawning stock in Chesapeake Bay has been partially protected from exploitation by a sanctuary in the spawning grounds (Lipcius et al. 2001, 2002b). However, the sanctuary and various exploitation controls have apparently not protected a sufficiently large fraction of the population (Seitz et al. 2001) to avert the observed reduction in the spawning stock.

Acknowledgements. We are indebted to the staff of the Crustacean Ecology Program, especially P. Gerdes and M. Seebo, and to the staff of the VIMS Trawl Survey, particularly D. Estes, P. Geer, T. Mathes and D. Seaver, for collection of the crab abundance data. We thank C. Bonzek and R. Harris of VIMS for their assistance with data management and analysis. This manuscript benefited greatly from comments by A. 'Tuck' Hines, R. Kneib, J. van Montfrans, G. Abbe, J. Hoenig, T. Miller, R. Seitz, and 3 anonymous reviewers. Assistance with crab illustrations was generously provided by R. Hershner and S. Stein; illustrations were drawn by K. Forrest. The trawl survey data for the blue crab resulted from the visionary commitment by Willard Van Engel to its careful collection. We also thank the Chesapeake Bay Monitoring Program (http:// www.chesapeakebay.net/monprgms.htm), particularly the principal investigators of the plankton monitoring projectR. Birdsong and K. Carpenter (Department of Biological Sciences, Old Dominion University, Norfolk, VA, USA) - for pro- 
viding plankton samples, and Jackie Johnson and Claire Buchanan for assistance with the plankton data files. Funding for the survey and its analysis has been provided by the Commonwealth of Virginia, the Chesapeake Bay Stock Assessment Committee, the National Oceanic and Atmospheric Administration (NOAA) through the Essential Fish Habitat program of the National Sea Grant Office and Virginia Sea Grant (NOAA), the Chesapeake Bay Commission, and the Chesapeake Bay Program. This is contribution number 2382 of the Virginia Institute of Marine Science.

\section{LITERATURE CITED}

Abbe GR, Stagg C (1996) Trends in blue crab (Callinectes sapidus Rathbun) catches near Calvert Cliffs, Maryland, from 1968 to 1995 and their relationship to the Maryland commercial fishery. J Shellfish Res 15:751-758

Alden RW, Dahiya RC, Young RJ (1982) A method for the enumeration of zooplankton samples. J Exp Mar Biol Ecol 59: 185-209

Allison GW, Lubchenco J, Carr MH (1998) Marine reserves are necessary but not sufficient for marine conservation. Ecol Appl 8(1)Suppl:S79-S92

Beacham TD (1983) Variability in median size and age at sexual maturity of Atlantic cod, Gadus morhua, on the Scotian shelf in the Northwest Atlantic Ocean. Fish Bull (Wash DC) $81: 303-321$

Beverton RJH, Holt SJ (1957) On the dynamics of exploited fish populations. Chapman \& Hall, London

Birdsong RS (1992) Zooplankton monitoring program. In: Virginia Chesapeake Bay water quality and living resources monitoring programs: Comprehensive Technical Report, 1985-1989. AMRL Tech Rept No. 848: Zooplankton, Old Dominion University, Norfolk, VA

Botsford LW, Castilla JC, Peterson CH (1997) The management of fisheries and marine ecosystems. Science 277: 509-515

Campbell A, Robinson DG (1983) Reproductive potential of three American lobster (Homarus americanus) stocks in the Canadian maritimes. Can J Fish Aquat Sci 40: 1958-1967

Caputi N, Chubb CF, Brown RS (1995) Relationships between spawning stock, environment, recruitment and fishing effort for the western rock lobster, Panulirus cygnus, fishery in Western Australia. Crustaceana 68:213-226

Charnov EL (1979) Natural selection and sex change in pandalid shrimp: test of a life-history theory. Am Nat 113: 715-734

Charnov EL, Gotshall DW, Robinson JG (1978) Sex ratio: adaptive response to population fluctuations in pandalid shrimp. Science 200:204-206

Chittleborough RG (1976) Breeding of Panulirus longipes cygnus George under natural and controlled conditions. Aust J Mar Freshw Res 27:499-516

Chittleborough RG (1979) Natural regulation of the population of Panulirus longipes cygnus George and responses to fishing pressure. Rapp P-V Réun Cons Perm Int Explor Mer 175:217-221

Condie SA, Loneragan NR, Die DJ (1999) Modelling the recruitment of tiger prawns Penaeus esculentus and $P$. semisulcatus to nursery grounds in the Gulf of Carpenteria, Australia: implications for assessing stock-recruitment relationships. Mar Ecol Prog Ser 178:55-68

Costlow JD Jr (1967) The effect of salinity and temperature on survival and metamorphosis of megalops of the blue crab, Callinectes sapidus. Helgol Wiss Meeresunters 15:84-97
Costlow JD Jr, Bookhout CG (1959) The larval development of Callinectes sapidus reared in the laboratory. Biol Bull 116:373-396

Eckman JE (1996) Closing the larval loop: linking larval biology to the population dynamics of marine benthic invertebrates. J Exp Mar Biol Ecol 200:207-237

Ennis GP, Fogarty MJ (1997) Recruitment overfishing reference point for the American lobster, Homarus americanus. Mar Freshw Res 48:1029-1034

Epifanio CE, Masse AK, Garvine RW (1989) Transport of blue crab larvae by surface currents off Delaware Bay, USA. Mar Ecol Prog Ser 54:35-41

Garcia SM (1996) Stock-recruitment relationships and the precautionary approach to management of tropical shrimp fisheries. Mar Freshw Res 47:43-58

Gliwicz ZM, Rykowska A (1992) 'Shore avoidance' in zooplankton: a predator-induced behaviour or predatorinduced mortality? J Plankton Res 14:1331-1342

Grosberg RK, Levitan DR (1992) For adults only? Supply-side ecology and the history of larval biology. Trends Ecol Evol $7: 130-133$

Guenette S, Lauck T, Clark C (1998) Marine reserves: from Beverton and Holt to the present. Rev Fish Biol Fish 8: 251-272

Guillory V, Hein S (1998) A review and evaluation of escape rings in blue crab traps. J Shellfish Res 17:551-559

Guillory V, Perret WS (1998) History, management, status, and trends in the Louisiana blue crab fishery. J Shellfish Res 17:413-424

Hammerschmidt P, Wagner T, Lewis G (1998) Status and trends in the Texas blue crab (Callinectes sapidus) fishery. J Shellfish Res 17:405-412

Hancock DA (1973) The relationship between stock and recruitment for exploited invertebrates. Rapp P-V Réun Cons Int Explor Mer 164:113-131

Hannah RW (1999) A new method for indexing spawning stock and recruitment in ocean shrimp, Pandalus jordani, and preliminary evidence for a stock-recruitment relationship. Fish Bull (Wash DC) 97:482-494

Hannah RW, Jones SA (1991) Fishery-induced changes in the population structure of pink shrimp Pandalus jordani. Fish Bull (Wash DC) 89:41-51

Hansen PM (1949) Studies on the biology of the cod in Greenland waters. Rapp P-V Réun Cons Perm Int Explor Mer 123:1-77

Hartnoll RG (1985) Growth, sexual maturity and reproductive output. In: Wenner A (ed) Crustacean issues, Vol 3. Balkema Press, Rotterdam, p 101-128

Hassell MP (1978) The dynamics of arthropod predator-prey systems. Princeton University Press, Princeton, NJ

Hata DN (1997) Comparison of gears and vessels used in the Virginia Institute of Marine Science juvenile finfish trawl survey. Va Inst Mar Sci Special Report in Applied Marine Science and Ocean Engineering No. 343

Hilborn R, Walters CJ (1992) Quantitative fisheries stock assessment: choice, dynamics and uncertainty. Chapman \& Hall, New York

Holbrook SJ, Schmitt RJ, Stephens JS Jr (1997) Changes in an assemblage of temperate reef fishes associated with a climate shift. Ecol Appl 7:1299-1310

Honkoop PJC, van der Meer J, Beukema JJ, Kwast D (1998) Does temperature-influenced egg production predict the recruitment in the bivalve Macoma balthica? Mar Ecol Prog Ser 164:229-235

Hughes TP (1994) Catastrophes, phase shifts, and large-scale degradation of a Caribbean coral reef. Science 265: $1547-1551$ 
Hughes TP, Tanner JE (2000) Recruitment failure, life histories, and long-term decline of Caribbean corals. Ecology 81:2250-2263

Hughes TP, Baird AH, Dinsdale EA, Moltschaniwskyj NA, Pratchett MS, Tanner JE, Willis BL (2000) Supply-side ecology works both ways: the link between benthic adults, fecundity, and larval recruits. Ecology 81:2241-2249

Jamieson GS (2001) Selective effects of fishing on the population dynamics of crustaceans. Can Spec Publ Fish Aquat Sci (In press)

Jamieson GS, Phillips A, Smith BD (1998) Implications of selective harvests in Dungeness crab (Cancer magister) fisheries. Can Spec Publ Fish Aquat Sci 125:309-321

Jones CM, McConaugha JR, Geer PJ, Prager MH (1990) Estimates of spawning stock size of blue crab, Callinectes sapidus, in Chesapeake Bay, 1986-1987. Bull Mar Sci 46: 159-169

Jorgensen T (1990) Long-term changes in age at sexual maturity of Northeast Arctic cod (Gadus morhua L.). J Cons Perm Int Explor Mer 46:235-248

Kahn DM, Cole RW, Michels SF, Whitmore WH (1998) Development of life-stage-specific indices of relative abundance and stock-recruitment relationships for the Delaware Bay blue crab stock. J Shellfish Res 17:529-542

Levitan DR (1991) Influence of body size and population density on fertilization success and reproductive output in a free-spawning invertebrate. Biol Bull 181-261-268

Lipcius RN (1985) Size-dependent timing of reproduction and molting in spiny lobsters and other long-lived decapods. In: Wenner A (ed) Crustacean issues, Vol. 3. Balkema Press, Rotterdam, p. 129-148

Lipcius RN, Van Engel WA (1990) Blue crab population dynamics in Chesapeake Bay: variation in abundance (York River, 1972-1988) and stock-recruit functions. Bull Mar Sci 46:180-194

Lipcius RN, Seitz RD, Goldsborough WJ, Montane MM, Stockhausen WT (2001) A deep-water dispersal corridor for adult female blue crabs in Chesapeake Bay. In: Kruse GH, Bez N, Booth A, Dorn MW and 6 others (eds) Sea Grant, AK-SG-01-02. Spatial processes and management of marine populations. University of Alaska, Fairbanks, AK, p 643-666

Lipcius RN, Montane MM, Rothschild BJ (2002a) Interannual decline, compensatory mortality, and conservation of the Chesapeake Bay blue crab population in winter. Fish Bull (Wash DC) (in press)

Lipcius RN, Stockhausen WT, Seitz RD, Geer PJ (2002b) Spatial dynamics of the blue crab spawning stock in a protected sanctuary-corridor network in Chesapeake Bay. Bull Mar Sci (in press)

McConaugha JR, Johnson DF, Provenzano AJ Jr, Maris RC (1983) Seasonal distribution of larvae of Callinectes sapidus (Crustacea: Decapoda) in the waters adjacent to Chesapeake Bay. J Crust Biol 3:582-591

Medley PAH, Ninnes CH (1997) A recruitment index and population model for spiny lobster (Panulirus argus) using catch and effort data. Can J Fish Aquat Sci 54: 1414-1421

Mense DJ, Wenner EW (1989) Distribution and abundance of early life history stages of the blue crab, Callinectes sapidus, in tidal marsh creeks near Charleston, S.C. Estuaries 12:157-168

Miller TJ, Houde ED (1998) Blue Crab Target Setting. Final Report to Chesapeake Bay Program. Ref No [UMCES] CBL 98-129. University of Maryland Center for Environmental Sciences, Chesapeake Biological Laboratory, Solomons, MD
Payne AIL (1989) Cape hakes. In: Payne AIL, Crawford RJM (eds) Oceans of life off Southern Africa. Vlaeberg, Cape Town, p 136-147

Perry HM, Warren J, Trigg C, Van Devender T (1998) The blue crab fishery of Mississippi. J Shellfish Res 17:425-433

Peterson CH, Summerson HC (1992) Basin-scale coherence of population dynamics of an exploited marine invertebrate, the bay scallop: implications of recruitment limitation. Mar Ecol Prog Ser 90:257-272

Policansky D (1993) Fishing as a cause of evolution in fishes. In: Stokes TK, McGlade JM, Law R (eds) The exploitation of evolving resources. Springer-Verlag, Heidelberg, p 2-18

Pollock DE (1995) Changes in maturation ages and sizes in crustacean and fish populations. S Afr J Mar Sci 15:99-103

Polovina JJ (1989) Density dependence in spiny lobster, Panulirus marginatus, in the northwestern Hawaiian islands. Can J Fish Aquat Sci 46:660-665

Prager MH (1996) A simple model of the blue crab, Callinectes sapidus, spawning migration in Chesapeake Bay. Bull Mar Sci 58:421-428

Prager MH, McConaugha JR, Jones CM, Geer PJ (1990) Fecundity of blue crab, Callinectes sapidus, in Chesapeake Bay: biological, statistical and management considerations. Bull Mar Sci 46:170-179

Provenzano AJ Jr, McConaugha JR, Phillips KB, Johnson DF, Clark J (1983) Vertical distribution of first stage larvae of the blue crab, Callinectes sapidus, at the mouth of Chesapeake Bay. Estuar Coast Shelf Sci 16:489-499

Roberts CM (1997) Connectivity and management of Caribbean coral reefs. Science 278:1454-1457

Rothlisberg PC, Craig PD, Andrewartha JR (1996) Modelling penaeid prawn larval advection in Albatross bay, Australia: defining the effective spawning population. Mar Freshw Res 47:157-167

Rothschild BJ (1986) Dynamics of marine fish populations. Harvard University Press, Cambridge, MA

Rothschild BJ, Ault JS (1992) Assessment of the Chesapeake Bay Blue Crab Stock. Final Report to Chesapeake Bay Program. Ref No [UMCES] CBL 92-082, University of Maryland Center for Environmental Sciences, Chesapeake Biological Laboratory, Solomons, MD

Rugolo LJ, Knotts KS, Lange AM, Crecco VA (1998) Stock assessment of Chesapeake Bay blue crab (Callinectes sapidus Rathbun). J Shellfish Res 17:493-517

Seitz RD, Lipcius RN, Stockhausen WT, Montane MM (2001) Efficacy of blue crab spawning sanctuaries in Chesapeake Bay. In: Kruse GH, Bez N, Booth A, Dorn MW and 6 others (eds) Spatial processes and management of marine populations. AK-SG-01-02, University of Alaska Sea Grant, Fairbanks, AK, p 607-626

Shelton PA, Armstrong MJ (1983) Variations in the parent stock and recruitment of pilchard and anchovy populations in the southern Benguela system. FAO Fish Rep 291: $1113-1132$

Smith BD, Jamieson GS (1991) Possible consequences of intensive fishing for males on the mating opportunities of Dungeness crabs. Trans Am Fish Soc 120:650-653

Sparkes TC (1996) Effects of predation risk on population variation in adult size in a stream-dwelling isopod. Oecologia 106:85-92

Steele JH, Henderson EW (1984) Modeling long-term fluctuations in fish stocks. Science 224:985-987

Tang Q (1985) Modification of the Ricker stock recruitment model to account for environmentally induced variation in recruitment with particular reference to the blue crab fishery in Chesapeake Bay. Fish Res (Amst) 3:13-21 
Underwood AJ (1997) Experiments in ecology. Cambridge University Press, Cambridge

Uphoff JH Jr (1998) Stability of the blue crab stock in Maryland's portion of Chesapeake Bay. J Shellfish Res 17: 519-528

Van Engel WA (1958) The blue crab and its fishery in the Chesapeake Bay. Part I. Reproduction, early development, growth, and migration. Commer Fish Rev 20:6-1

van Montfrans J, Peery CA, Orth RJ (1990) Daily, monthly and annual settlement patterns by Callinectes sapidus and Neopanope sayi on artificial collectors deployed in the York River, Virginia. Bull Mar Sci 46:214-228

van Montfrans J, Epifanio CE, Knott DM, Lipcius RN and 6 others (1995) Settlement of blue crab postlarvae in Western North Atlantic estuaries. Bull Mar Sci 57:834-854

Editorial responsibility: Ronald Kneib (Contributing Editor), Sapelo Island, Georgia, USA
Wellborn GA (1994) Size-biased predation and prey life histories: a comparative study of freshwater amphipod populations. Ecology 75:2104-2117

Whitaker JD, DeLancey LB, Jenkins JE, Maddox MB (1998) A review of the fishery and biology of the blue crab, Callinectes sapidus, in South Carolina. J Shellfish Res 17:459-463

Williams AB (1984) Shrimps, lobsters, and crabs of the Atlantic coast of the eastern United States, Maine to Florida. Smithsonian Institution Press, Washington, DC

Ye Y (2000) Is recruitment related to spawning stock in penaeid shrimp fisheries? ICES J Mar Sci 57:1103-1109

Zheng J, Murphy MC, Kruse GH (1995) A length-based population model and stock-recruitment relationships for red king crab, Paralithodes camtschaticus, in Bristol Bay, Alaska. Can J Fish Aquat Sci 52:1229-1246

Submitted: December 12, 1999; Accepted: May 26, 2001 Proofs received from author(s): January 18, 2002 